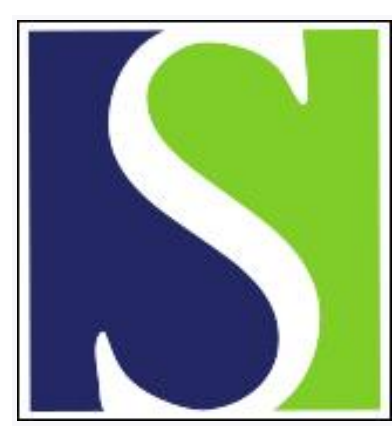

Scand J Work Environ Health 1997;23(1):41-47

https://doi.org/10.5271/sjweh.177

Issue date: Feb 1997

Fibrosis of the lung and pleura and long-term exposure to wollastonite

by Koskinen HO, Nordman HL, Zitting AJ, Suoranta HT, Anttila SL, Taikina-aho OSA, Luukkonen RA

Key terms: asbestos; bronchoalveolar lavage; chest radiography; high-resolution computed tomography; HRCT; lung function; lung tissue analysis; mineral fiber

This article in PubMed: www.ncbi.nlm.nih.gov/pubmed/9098911

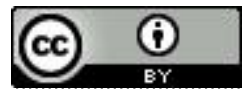




\title{
Fibrosis of the lung and pleura and long-term exposure to wollastonite
}

\author{
by Heikki O Koskinen, MD, ${ }^{1}$ Henrik L Nordman, MD, ${ }^{1}$ Anders J Zitting, MD, ${ }^{1}$ Hannu T Suoranta, MD, ${ }^{2}$ \\ Sisko L Anttila, MD, ${ }^{1}$ Olavi SA Taikina-aho, MSC, ${ }^{3}$ Ritva A Luukkonen, $S C D^{1}$
}

\begin{abstract}
Koskinen HO, Nordman HL, Zitting AJ, Suoranta HT, Anttila SL, Taikina-aho OSA, Luukkonen RA. Fibrosis of the lung and pleura and long-term exposure to wollastonite. Scand J Work Environ Health 1997;23(1): $41-7$.
\end{abstract}

Objectives The purpose of this study was to determine whether long-term exposure to wollastonite causes fibrosis of the lung and pleura in humans.

Methods Forty-nine workers (mean exposure 25 years) in a Finnish limestone-wollastonite mine and mill were examined. Their work histories and symptoms of chronic bronchitis were recorded. The chest radiographs were classified according to the classification of the International Labour Office (1980); a radiographic follow-up from 1981 to 1990 was included. Spirometry and diffusion capacity were measured. Four workers underwent high-resolution computed tomography (HRCT) and bronchoalveolar lavage (BAL). Lung tissue specimens were available for 2 workers. Mineral fibers and asbestos bodies were analyzed from the BAL fluid and lung tissue specimens, which were also analyzed for lung fibrosis.

Results Two workers (4\%) had small irregular lung opacities (ILO 1/0), 1 worker (2\%) ILO 0/1 of the s/t type. HRCT revealed no parenchymal fibrosis in the 2 workers with the ILO $1 / 0$ classification. Of the 9 workers (18\%) with pleural plaques, 5 had been exposed to asbestos. Multivariate logistic regression analyses revealed no association of plaques with the duration of wollastonite or asbestos exposure. Wollastonite fibers or bodies were not found in any of the 4 workers who underwent BAL, nor in either of the workers whose lung tissue specimens were available.

Conclusions No evidence was found that long-term exposure to wollastonite causes parenchymal fibrosis of the lung and pleura. Furthermore, the findings indicate that wollastonite fibers are poorly retained in human lungs.

Key terms asbestos, bronchoalveolar lavage, chest radiography, high-resolution computed tomography, lung function, lung tissue analysis, mineral fiber.

Wollastonite is an acicular or fibrous silicate mineral $\left(\mathrm{CaSiO}_{3}\right)$. The largest deposits of wollastonite are located in the United States (US), Mexico, and Finland (1).

Wollastonite excavation from the sole Finnish mine began in the 1950s, even though limestone had been quarried from this open pit since 1911. From 1962 to 1991 the annual production of wollastonite varied from 2440 to 31490 t. About $70 \%$ to $75 \%$ of Finnish wollastonite is used in the ceramics industry.

Currently, knowledge on the respiratory effects of wollastonite on humans is limited to that concerning 2 cohorts, one consisting of Finnish wollastonite workers (1) and the other of US workers (2). The Finnish wollastonite workers had a high radiographic prevalence $(30 \%)$ of low-level profusion of opacities (ILO category $1 / 0$ to
1/1) and a high prevalence (28\%) of pleural plaques in contrast to the US workers, who showed a low prevalence $(3 \%)$ of pneumoconiosis in ILO category 1 and no pleural plaques.

Forty-six men working in the Finnish wollastonite mine were examined for respiratory effects in 1981 (1). We have subsequently followed a group of Finnish wollastonite workers radiographically from 1981 to 1990. We were also able to use more sophisticated methods, such as high-resolution computed tomography (HRCT) of the lungs and bronchoalveolar lavage (BAL) to assess fibrosis of the lung and pleura and to determine exposure to wollastonite. In addition, lung tissue specimens obtained at autopsy were available from 2 wollastonite workers.

1 Finnish Institute of Occupational Health, Helsinki, Finland.

2 Mediscan Ltd, Helsinki, Finland.

3 University of Oulu, Institute of Electron Optics, Oulu, Finland.

Reprint requests to: Dr Heikki Koskinen, Finnish Institute of Occupational Health, Topeliuksenkatu 41 a A, FIN-00250 Helsinki, Finland. 


\section{Subjects and methods}

\section{Exposure}

The mean concentrations of total dust in the Finnish limestone-wollastonite open pit mine and mill varied in 1981 from 0.3 to $67 \mathrm{mg} / \mathrm{m}^{3}$ and that of fibers (f) from 5.1 to $33 \mathrm{f} / \mathrm{cm}^{3}$ (in phase-contrast optical microscopy) or from 2.6 to $52 \mathrm{f} / \mathrm{cm}^{3}$ (in scanning electron microscopy)(1). In addition to calcite, the average respirable fraction contained $15 \%$ wollastonite and $3 \%$ quartz. Later dust measurements (optical method) revealed fiber concentrations ranging from 0.04 to $3.4 \mathrm{f} / \mathrm{cm}^{3}$ for wollastonite mining and milling and from 0.09 to $1.2 \mathrm{f} / \mathrm{cm}^{3}$ for calcite mining and milling at worksites where fibers were detected in airborne dust samples. In a recent hygienic survey, tremolite fibers were also observed sporadically in airborne dust samples in calcite mining and milling (in secondary crushing $\left.0.1 \mathrm{f} / \mathrm{cm}^{3}\right)(3)$.

\section{Subjects}

A cohort was formed in 1981 of 56 workers (47 men and 9 women) exposed to dust at the Finnish limestonewollastonite mine. Almost all of the living workers with the longest work experience in the mine were included. They were examined in 1981, and the observations on the male subcohort of 46 workers with 10 years or more of exposure were reported in 1983 (1). The inclusion criterion for the initial cohort was least 10 years of work in the mine. However, in the reclassification of exposure duration, it was found that 1 male worker had been exposed for 4 years and 2 female workers for 9 years. The Finnish limestone-wollastonite mine has been in operation since 1911. From 1923 to 1980 altogether 238 workers (192 men and 46 women) were on the payroll for at least 1 year (4). In $1980,159(67 \%)$ of them were alive, and this group served as the source population for the initial cohort in 1981.

In 1990 the entire initial cohort of 56 mine and mill workers was invited to a clinical reexamination; 7 workers declined. Between May and October 1990 we examined the remaining 49 workers ( 40 men and 9 women); thus, 40 of the 46 examined in 1981 were re-examined. Table 1 gives the distributions by gender, age, exposure duration in wollastonite mine and mill work, and years since first exposure. Twenty-four of the workers (49\%) had retired by 1990 , though none due to respiratory disease. Twelve (24\%) had also worked elsewhere for the company (eg, in the rockwool or cement factories).

The detection of asbestos fibers and bodies in BAL fluid prompted us to classify the subjects' history of exposure to asbestos (no, possible, probable) or rockwool (no, yes) from all work tasks. Thirteen of the workers (27\%) had been slightly exposed to asbestos, 9 being classified as possibly and 4 as probably exposed inside or outside company facilities. Nine workers $(18 \%)$ had experienced exposure to man-made mineral fibers (MMMF) in the rockwool factory of the company; 3 of them also belonged to the asbestos-exposed group. Thus 19 workers (39\%) had experienced some degree of exposure to mineral fibers other than wollastonite. The duration of exposure to asbestos ranged from 2 to 30 (mean 10, SD 8.3) years $(\mathrm{N}=13)$, and that of MMMF from 1 to 20 (mean 2, SD 5.6) years $(\mathrm{N}=9$ ). Probably none of the workers had experienced environmental asbestos exposure to a significant degree.

Eight subjects with a radiographic finding of small lung opacities of ILO $0 / 1$ or more (5) or with bilateral pleural plaques were selected for further examination, including HRCT and BAL. Two of them suffered from coronary heart disease and were excluded due to the severity of their symptoms; 2 others refused to be examined. Thus, in May and June 1991, HRCT and BAL were performed on 4 male workers.

Since the cross-sectional survey in 1990, 2 members of the cohort have died (in 1993 and 1994), both from a nonpulmonary disease. Lung tissue specimens were obtained from both at autopsy. In 1 case (subject B, tables 2 and 3) the right lung was fixed and diluted with $10 \%$ formalin via the bronchi, and samples for macroscopic and histological examination, as well as for mineral fiber analysis, were available. The lung tissue specimens from the other worker were so few that only the mineral fiber content could be analyzed.

Table 1. Gender, age, exposure duration, and years since first exposure in the wollastonite mine and in mill work, plus smoking habits and symptoms of chronic bronchitis in 49 wollastonite workers.

\begin{tabular}{|c|c|c|c|c|c|c|c|c|c|c|c|c|c|c|}
\hline & \multicolumn{2}{|c|}{ Age (years) } & \multicolumn{2}{|c|}{$\begin{array}{c}\text { Exposure } \\
\text { duration (years) }\end{array}$} & \multicolumn{2}{|c|}{$\begin{array}{l}\text { Years since first } \\
\text { exposure (years) }\end{array}$} & \multicolumn{6}{|c|}{ Smoking habits } & \multicolumn{2}{|c|}{$\begin{array}{c}\text { Chronic } \\
\text { bronchitisa }\end{array}$} \\
\hline & \multirow[t]{2}{*}{ Mean } & \multirow[t]{2}{*}{ Range } & \multirow[t]{2}{*}{ Mean } & \multirow[t]{2}{*}{ Range } & \multirow[t]{2}{*}{ Mean } & \multirow[t]{2}{*}{ Range } & \multicolumn{2}{|c|}{ Smoker } & \multicolumn{2}{|c|}{ Exsmoker } & \multicolumn{2}{|c|}{ Nonsmoker } & \multirow[t]{2}{*}{$N$} & \multirow[t]{2}{*}{$\%$} \\
\hline & & & & & & & $N$ & $\%$ & $N$ & $\%$ & $N$ & $\%$ & & \\
\hline $\begin{array}{l}\text { Men }(N=40) \\
\text { Women }(N=9) \\
\text { All }(N=49)\end{array}$ & $\begin{array}{l}58 \\
57 \\
57\end{array}$ & $\begin{array}{l}42-74 \\
41-69 \\
41-74\end{array}$ & $\begin{array}{l}27 \\
13 \\
25\end{array}$ & $\begin{array}{l}4-42 \\
9-26 \\
4-42\end{array}$ & $\begin{array}{l}33 \\
22 \\
31\end{array}$ & $\begin{array}{l}24-54 \\
19-25 \\
19-54\end{array}$ & $\begin{array}{r}13 \\
4 \\
17\end{array}$ & $\begin{array}{l}33 \\
44 \\
35\end{array}$ & $\begin{array}{r}16 \\
0 \\
16\end{array}$ & $\begin{array}{r}40 \\
0 \\
33\end{array}$ & $\begin{array}{r}11 \\
5 \\
16\end{array}$ & $\begin{array}{l}28 \\
56 \\
33\end{array}$ & $\begin{array}{r}12 \\
2 \\
14\end{array}$ & $\begin{array}{l}25 \\
22 \\
29\end{array}$ \\
\hline
\end{tabular}

a Chronic bronchitis defined as the production of phlegm for at least 3 months each year for 2 years or more. 
Table 2. Occupation in relation to the radiographic HRCT and BAL findings of 4 male mine workers. (ILO = International Labour Office, $\mathrm{HRCT}=$ high-resolution computed tomography, $\mathrm{BAL}=$ branchoalveolar lavage, $\mathrm{TEM}=$ transmission electron microscopy, $f=$ fibers, $\mathrm{ab}=$ asbestos bodies, $\mathrm{ND}=$ not detected)

\begin{tabular}{|c|c|c|c|c|}
\hline Main occupation & Radiographic finding (ILO) & HRCT finding & $\begin{array}{l}\text { Fibers or } \\
\text { asbestos bodies in } B A L^{a}\end{array}$ & Asbestos bodies ${ }^{b}$ \\
\hline A. Driller & $\begin{array}{l}1 / 0, \text { st; pleural plaques: chest wall, uni- } \\
\text { lateral, circumscribed, face on, width b, } \\
\text { extent } 1 \text { and diaphragm, unilateral; } \\
\text { plaques calcified, extent } 2\end{array}$ & $\begin{array}{l}\text { No parenchymal findings; pleural } \\
\text { plaques: chest wall, bilateral, width } \\
>3 \mathrm{~mm} \text {, extent } 2-5 \mathrm{~cm} \text { and diaphragm; } \\
\text { plaques calcified }\end{array}$ & $81 \mathrm{f} / \mathrm{ml},{ }^{,} 54 \mathrm{ab} / \mathrm{ml}$ & $11 \mathrm{ab} / \mathrm{ml}$ \\
\hline B. Driller & $\begin{array}{l}\text { 0/0; pleural plaques: chest wall; } \\
\text { bilateral, circumscribed, face on, width } \\
\text { b, extent } 1 \text { on both sites }\end{array}$ & $\begin{array}{l}\text { No parenchymal findings' pleural } \\
\text { plaques: chest wall, bilateral, width } \\
1-3 \mathrm{~mm} \text {, extent } 2-5 \mathrm{~cm}\end{array}$ & $\begin{array}{l}108 \mathrm{f} /\left.\mathrm{m}\right|^{d} \\
27 \mathrm{f} /\left.\mathrm{m}\right|^{\mathrm{e}}\end{array}$ & ND \\
\hline $\begin{array}{l}\text { C. Transport } \\
\text { worker }\end{array}$ & $\begin{array}{l}\text { 0/0; pleural plaques: chest wall, } \\
\text { bilateral, circumscribed, face on, width } \\
\text { b, extent } 2 \text { (right), width a, extent } 2 \\
\text { (left); plaques calcified extent } 1 \text { (both } \\
\text { sites) }\end{array}$ & $\begin{array}{l}\text { No parenchymal findings; pleural } \\
\text { plaques: chest wall, bilateral, } \\
\text { width > } 3 \mathrm{~mm} \text {, extent } 2-5 \mathrm{~cm} \text { and } \\
\text { diaphragm, bilateral; plaques calcified }\end{array}$ & ND & $\mathrm{ND}$ \\
\hline D. Sorter & $1 / 0$, s/t; no pleural findings & $\begin{array}{l}\text { No parenchymal findings; no pleural } \\
\text { findings }\end{array}$ & ND & $0.3 \mathrm{ab} / \mathrm{ml}$ \\
\hline
\end{tabular}

\section{a TEM}

Light microscopy

- Anthophylite

d Chrysotile

e Crocidolite

Table 3. Data on the 9 male subjects with pleural plaques in chest radiographs in 1990.

\begin{tabular}{|c|c|c|c|c|}
\hline \multirow[t]{2}{*}{ Main occupation } & \multicolumn{2}{|c|}{ Exposure to wollastonite } & \multirow[t]{2}{*}{ Asbestos exposure } & \multirow[t]{2}{*}{ Pleural finding } \\
\hline & $\begin{array}{l}\text { Duration } \\
\text { (years) }\end{array}$ & $\begin{array}{l}\text { Years since } \\
\text { first expo- } \\
\text { sure }\end{array}$ & & \\
\hline A. Driller & 19 & 27 & Probable $^{a}$ & $\begin{array}{l}\text { Chest wall: unilateral, circumscribed; face on, width b, extent } 1 . \\
\text { Diaphragm: unilateral; plaques calcified: extent } 2\end{array}$ \\
\hline B. Driller & 28 & 33 & $\mathrm{~N}_{0} \mathrm{~b}$ & $\begin{array}{l}\text { Chest wall: bilateral, circumscribed; face on, width b, extent } 1 \text { on } \\
\text { both sites }\end{array}$ \\
\hline C. Transport worker & 25 & 32 & No & $\begin{array}{l}\text { Chest wall: bilateral, circumscribed; face on, width a, extent } 1 \\
\text { (right), width b, extent } 2 \text { (left); diaphragm: bilateral, calcified, } \\
\text { extent } 1 \text { on both sites }\end{array}$ \\
\hline E. Transport worker & 25 & 30 & No & $\begin{array}{l}\text { Chest wall: bilateral, circumscribed; face on, width a, extent 2; } \\
\text { diaphragm: unilateral }\end{array}$ \\
\hline F. Transport worker & 23 & 30 & No & Chest wall: unilateral, circumscribed; face on, width 0 , extent 2 \\
\hline G. Mine maintenance worker & 41 & 58 & Probable & $\begin{array}{l}\text { Chest wall: bilateral, circumscribed; face on, width a, extent 1; } \\
\text { diaphragm: bilateral (progression of plaques) }\end{array}$ \\
\hline H. Plant supervisor & 18 & 28 & No & $\begin{array}{l}\text { Chest wall: bilateral, circumscribed; face on, width } 0 \text {, extent } 1 \\
\text { (right), extent } 2 \text { (left) (progression of plaques) }\end{array}$ \\
\hline I. Flotation plant worker & 4 & 43 & Possible & $\begin{array}{l}\text { Chest wall: unilateral, circumscribed; face on, width } 0 \text {, extent } 1 \text {; } \\
\text { diaphragm: unilateral (progression of plaques) }\end{array}$ \\
\hline J. Sorter & 20 & 25 & Probable & $\begin{array}{l}\text { Chest wall: unilateral, circumscribed; face on, width } 1 \text {, extent } 1 . \\
\text { (progression of plaques) }\end{array}$ \\
\hline
\end{tabular}

a Before 1962 occasionally a stoker in a tug with a steam engine; from 1978 to 1983 a blacksmith in the mine workshop using asbestos gloves and asbestos tapes; from 1983 to 1990 a repairman in the mine workshop performing (eg, brake repair); bronchoalveolar lavage: 11 ab/ml; transmission electron microscopy: 81 anthophyllite fibers/ml.

- Bronchoalveolar lavage: transmission electron microscopy, 108 chrysotile fibers $/ \mathrm{ml}, 27$ crocidolite fibers $/ \mathrm{ml}$.

c From 1963 to 1983 a repairman in the mine workshop; tasks included brake repair.

d From 1951 to 1981 a repairman in the cement factory; tasks included furnace demolition.

e From 1945 to 1965 a construction worker.

\section{Interview and clinical examination}

The occupational and medical histories, smoking habits, and bronchitis symptoms of the subjects were obtained in personal interviews. A modified version of the Medi- cal Research Council's questionnaire (6) was used to assess symptoms indicative of chronic bronchitis. Occupational exposures to wollastonite, asbestos, and rockwool were recorded on the basis of the data obtained from these interviews. 


\section{Chest radiography}

The examination included full-size posteroanterior radiographs. They were classified by two radiologists (AZ, a NIOSH B-reader since 1988, and HS) in 3 sessions over a 2-week period using the 1980 classification of the International Labour Office (ILO) (5). The readers were not aware of personal identities, and the dates of the chest radiographs, but they did know the occupational nature of the cohort. The 98 chest radiographs ( 2 for each subject) were classified into ILO categories in random order. The readers inspected the radiographs together and agreed with the ILO classifications jointly. The progression was judged by comparing the ILO score of each subject.

\section{High-resolution computed tomography}

HRCT of the thorax was performed with a whole-body unit (Toshiba $80 \mathrm{~A}$ ). Two-millimeter collimation was used and 5 supine scans were taken, the lowest scan at the level of the diaphragm and the succeeding ones about $3-\mathrm{cm}$ apart. The highest scan was thus taken at about the level of the pulmonary hila. For the subjects with findings observed in a supine scan, scans were taken with the subject in both a supine and prone position. Standard lung and soft-tissue windows were used. The HRCT findings were classified jointly by the same two radiologists at a separate session and without knowledge of the chest radiograph findings. The parenchymal HRCT findings were classified according to proposals by authors such as Lynch et al (7).

\section{Lung function measurements}

A flow-volume spirometer (Medikro 101, Finland; Vicatest 300 Mijnhardt) was used to measure the following lung function variables: vital capacity (VC), forced vital capacity (FVC), forced expiratory volume in $1 \mathrm{~s}\left(\mathrm{FEV}_{1.0}\right)$, maximum expiratory flow at $50 \%$ and $25 \% \mathrm{FVC}\left(\mathrm{MEF}_{50}\right.$ and $\mathrm{MEF}_{25}$, respectively), and maximum midexpiratory flow (MMEF). The single breath carbon monoxide diffusion capacity (DL) and the diffusion capacity in relation to alveolar volume (DL/VA) were measured with a transfer apparatus (Morgan, England). Finnish reference values were used (8).

\section{Mineral fiber analysis and asbestos body counting in bronchoalveolar lavage fluid}

BAL of the middle lobe was performed according to a standard procedure (9).

For the mineral fiber analysis by transmission electron microscopy (TEM), a 20-ml sample of BAL fluid was prepared as described earlier (10). The sample for TEM was prepared according to the modified Jaffe Washer technique (11).

The fiber (f) and asbestos body (ab) counting and the mineral identification were done with a Jeol $100 \mathrm{CX}$ ASID4D electron microscope $(100 \mathrm{kV})$ and a LINK AN10-25X X-ray microanalyzer. From the 20 -ml sample of BAL fluid a series of dilutions was filtered and prepared for TEM. Thirty to forty 150 -mesh copper grid squares were counted at a magnification of $10000 \times$. All the fibers and acicular minerals were analyzed with the X-ray microanalyzer at an analytical sensitivity of $20 \mathrm{f} / \mathrm{ml}$.

For asbestos body counting with a light microscope, $10 \mathrm{ml}$ of BAL fluid was fixed in the same volume of $96 \%$ ethanol. A Millipore filter preparation with staining for iron was readied as described previously (12). Asbestos bodies were counted by screening each consecutive visual field systematically at a magnification of $200 \times$.

\section{Mineral fiber analysis of lung tissue}

A 100-mg sample of formalin-fixed lung tissue was prepared with a low-temperature ashing technique to remove organic tissue (13). The TEM technique used was similar to that of the mineral fiber analysis of BAL fluid. Twenty to forty $150-$ mesh grid squares were studied at a magnification of $10000 \times$ to attain the analytical sensitivity of 0.025 million fibers per gram of dry lung tissue.

\section{Statistical methods}

Multivariate logistic regression was used to determine both the prevalence of pleural plaques as a function of exposure years for wollastonite, asbestos, and MMMF with time since first exposure as a covariate and the prevalence of the symptoms of chronic bronchitis as a function of years of exposure to wollastonite, asbestos, and MMMF with smoking habits as a covariate. The odds ratios (OR) and their 95\% confidence intervals (95\% CI) were estimated. Pearson's correlation coefficients were computed to describe the correlation of the lung function variables (percentages of the predicted values) with the years of exposure to wollastonite, asbestos, and MMMF and with years since first exposure to wollastonite.

\section{Results}

Two of the 49 wollastonite workers ( $4 \%$, both men) had small irregular opacities (ILO s/t) of ILO profusion $1 / 0$, and 1 worker had profusion of ILO $0 / 1$ in the middle and lower lung zones. These 3 workers $(49,51$, and 65 years of age) had been exposed at the mine and mill for 27,32 
and 40 years, and their latency times since first exposure were 27, 32 and 44 years, respectively. A comparison of the radiographic findings in 1981 and 1990 revealed radiographic progression of small opacities in 2 of the 3 men.

Table 2 shows the radiographic, HRCT, and BAL findings of the 4 workers who underwent HRCT and BAL. None of the 4 ( 2 with an ILO 1/0 classification for lung opacities) had parenchymal findings consistent with fibrosis in the HRCT. Lung-tissue specimens obtained at autopsy were available from subject $B$, who had been given an ILO classification of $0 / 0$. Neither his macroscopic nor his histologic findings showed fibrosis of the parenchymal lung or visceral pleura, although, histologically, slight centrilobular emphysema was seen. For 3 workers the radiographic finding of pleural plaques was confirmed by the HRCT. For 1 of the 3 (subject A, table 2) bilateral plaques were classified in the HRCT examination in contrast to the unilateral plaques seen in the plain chest radiograph. Wollastonite fibers could not be detected in the BAL fluid of the 4 workers, and neither wollastonite fibers nor wollastonite bodies were found in the lung tissue samples of subject B. At the time of the BAL, 2 of the 4 workers were currently (in 1990) exposed to dust at the mine (subject $A$ as a mine repairman, subject $B$ as a driller). The dust exposure of the other 2 had already ceased ( 5 years earlier for subject D and 9 years earlier for subject $\mathrm{C}$ ). A few crocidolite, anthophyllite or chrysotile fibers $(27-108 \mathrm{f} / \mathrm{ml}$ in the TEM results) and asbestos bodies $(0.3$ and $11 \mathrm{ab} / \mathrm{ml}$, in the light microscopic results) were identified in the BAL fluid. Subject D, who had no indication of pleural plaques but did have an asbestos concentration of $0.3 / \mathrm{ml}$ in his BAL fluid, may have been exposed to asbestos when working for 6 months in 1943 in the cement factory of the company. Subject A, with bilateral pleural plaques in the HRCT, had both asbestos fibers and bodies in his BAL fluid. He was basically a driller but currently also worked as a mine repairman. He had probably been exposed to asbestos in the $1950 \mathrm{~s}$ in the engine rooms of ships and was also currently exposed slightly when repairing brakes at the mine workshop. Subject C, with bilateral plaques, had no asbestos fibers or bodies in his BAL fluid and, according to his occupational history, had not been exposed to asbestos or MMMF. Subject B, with bilateral plaques, had the highest asbestos fiber (crocidolite and chrysotile) concentration in his BAL fluid, despite having no occupational history disclosing exposure to asbestos. He had worked as a driller at the mine between 1957 and 1979 and also from 1984 to 1994; from 1979 to 1984 he had been a deep driller in prospecting. In 3 of the lung-tissue samples obtained at autopsy from the apical and anterior segments of the upper lobe and from the basal part of the lower lobe of the right lung, the total TEM fiber count ranged from 0.12 to 0.84 million fibers per gram of dry tissue (tremolite asbestos from 0.06 to 0.14 million fibers per gram of dry tissue, anthophyllite from 0.03 to 0.6 million fibers per gram of dry tissue).

In addition, lung-tissue specimens for mineral fiber analysis were obtained at autopsy from a transport worker who radiographically displayed neither parenchymal nor pleural fibrosis. He had worked in the wollastonite mine from 1951 to 1986 . His occupational history revealed possible slight exposure to asbestos from 1951 to 1956 while working as a lubricator of dumpers (brakes). The fiber TEM count revealed small quantities of asbestos fibers ( 0.37 million anthophyllite and 0.05 million crocidolite fibers per gram of dry tissue) but no wollastonite fibers or bodies.

Nine of the wollastonite workers (18\%) had unilateral or bilateral pleural plaques radiographically. Table 3 shows their individual exposure characteristics and pleural findings. Their occupational histories revealed that 4 of them had also been exposed to asbestos (possibly or probably), and 2 of the 4 had had MMMF exposure as well. Thus, while the occupational history disclosed no asbestos exposure for 5 workers with plaques, 1 of them (subject B) had asbestos fibers in his BAL fluid and lung tissue specimens. Five of the 9 workers with pleural plaques displayed a radiographic progression of plaques from 1981 to 1990 . The multivariate logistic regression with time since first exposure as a covariate did not indicate an increased risk for pleural plaques in relation of years of exposure to wollastonite (OR 0.90, 95\% CI 0.80-1.02), asbestos (OR 1.10, 95\% CI $0.92-1.30$ ) or MMMF (OR $1.07,95 \%$ CI $0.76-$ $1.48)$.

Thickening of the visceral pleura (basal thickening of the costal pleura with obliterated costophrenic angle), which was progressive radiographically from 1981 to 1990, was found in 1 wollastonite worker, who also had asbestos fibers in his BAL fluid and lung tissue samples (subject B, table 2).

None of the 3 workers with small opacities (ILO $0 / 1-1 / 0)$ had impaired VC, FVC $(<80 \%$ of the predicted value), or DL ( $<75 \%$ of the predicted value).

In the Pearson's correlation analyses the lung function values [or $\mathrm{VC}, \mathrm{FVC} ; \mathrm{FEV}_{1,0}, \mathrm{MEF}_{50}, \mathrm{MEF}_{25}, \mathrm{MMEF}$, DL, and DL/VA (percentages of the predicted values)] did not correlate with the years of exposure at the limestone-wollastonite mine and mill (correlation coefficients from -0.01 to +0.22 ), the years since first exposure in mining and milling (from -0.05 to +0.27 ), the years of exposure to asbestos (from -0.18 to +0.43 ), or the years of exposure to MMMF (from -0.28 to +0.22 ).

Table 1 shows the smoking habits and the prevalence of symptoms indicative of chronic bronchitis. Multivariate logistic regression with smoking habits as a covariate did not indicate an increased risk for chronic bronchitis 
in relation to years of exposure to wollastonite (OR 1.01, 95\% CI 0.94-1.08), asbestos $(1.00,95 \%$ CI $0.90-$ 1.11 ) or MMMF (OR 1.17, 95\% CI 0.98-1.39).

\section{Discussion}

Two (4\%) of the limestone-wollastonite mine and mill workers radiographically showed irregular opacities (ILO 1/0) suggestive of diffuse interstitial lung fibrosis. However, the finding of parenchymal fibrosis in these 2 was not confirmed in the HRCT, even though this method is considered to be more sensitive than chest radiography for detecting parenchymal fibrosis (14).

A $30 \%$ prevalence of low-level ILO profusion (1/0: 6 workers, 1/1: 8 workers) was previously reported for essentially the same male subcohort. [Forty of the 46 male workers of a previous study (1) were reexamined in 1990.] Of those not examined in 1990, 3 were given an ILO classification of $1 / 1,2$ an ILO classification of $1 / 0$, and 1 an ILO classification of $0 / 0$ in the previous study. In our current study the previous classification was regarded as too sensitive with respect to the low-level profusion of small opacities. In fact, the observed difference between the two radiographic classifications of small opacities was subtle, since the range in the previous study in 1981 was only up to ILO $1 / 1$. For our male subcohort the prevalence of pleural plaques was similar to that observed in 1981 (23\% versus 28\%).

Exposure to asbestos as the cause of pleural plaques was not assessed in 1981. In our current study 4 of the 9 wollastonite workers with pleural plaques had occupational histories indicating slight exposure to asbestos. One worker with plaques (subject B, tables 2 and 3 ) had asbestos fibers in his BAL fluid and lung tissue specimens. Four workers with pleural plaques lacked any indication of asbestos exposure, and therefore an association between wollastonite exposure and pleural plaques was possible for these workers. However, such an association would be difficult to explain biologically. None of the 4 workers subjected to BAL had wollastonite fibers in their BAL fluid, nor were wollastonite fibers found in the lung tissue of the 2 examined workers. Thus long-term exposure to the wollastonite concentrations in question would not seem to cause any detectable retention of wollastonite fibers in the lung. However, this conclusion is based on very few observations. A multiple logistic regression revealed no increased risk of developing pleural plaques in relation to exposure to wollastonite, asbestos, or MMMF. Therefore, the etiology of pleural plaques in wollastonite workers remains unclear.

We were somewhat surprised to find no wollastonite fibers or protein-coated wollastonite bodies in the BAL fluid of the 4 workers examined or in the lung tissue of
2 workers. The failure to detect wollastonite fibers may be due to clearance from the lungs or to the solubility of wollastonite in body fluids or both. Moderate solubility of wollastonite in a medium similar to lung fluid has been observed in vitro (15). In a short-term inhalation bioassay of rats, wollastonite fibers were deposited preferentially at alveolar duct bifurcations and they cleared rapidly, the clearance half-time being approximately 1 week (16). The analytical sensitivity of our TEM method (20 f/ml; $0.025 \mathrm{f} / \mathrm{g}$ of dry lung tissue) plus light microscopy $(0.1 \mathrm{ab} / \mathrm{ml})$, both of which have proved useful in asbestos counting, may have been too weak for detecting low particle densities. Thus low concentrations of wollastonite fibers in the BAL fluid or lung tissue cannot be excluded.

The wollastonite workers in our study represent the workers of the Finnish mine and mill with the longest exposure to wollastonite. The subgroup of workers subjected to BAL and HRCT was formed from those with findings suggesting lung fibrosis (all of them) or the most advanced pleural plaques (bilateral). Because 4 of the 8 workers selected for BAL and HRCT dropped out, the workers examined represented workers who had radiographic findings consistent with parenchymal fibrosis, but not those with pleural plaques or the entire cohort.

US wollastonite workers have also shown a low prevalence of pneumoconiosis classified into ILO category 1 (2). By contrast, the opacities were rounded in each case in the US study, and no pleural abnormalities were detected. However, HRCT was not used. The Finnish cohort had a long latency since first exposure to wollastonite (mean 31 and range $19-54$ years) and a longer duration of exposure to wollastonite than the US cohort (mean 25 and range $10-11$ years). Furthermore, exposure to asbestos could be ascertained for $28 \%$ of the Finnish workers. Thus the differences in the dust exposure patterns may explain the contradictory pleural plaque observations. Neither study indicated any association of bronchitic symptoms with dust exposure. We found no correlation between the lung function variables and the duration of exposure to wollastonite mine and mill work. The US study demonstrated an obstructive ventilatory effect from wollastonite dust exposure when more sophisticated methods of assessing dust exposure were used.

In conclusion, our observations did not produce any evidence indicating that long-term exposure to wollastonite causes parenchymal fibrosis of the lungs. If wollastonite is fibrogenic, such a property cannot be strong. The exposed cohort showed pleural plaques. As the risk of contracting plaques was not related to the duration of wollastonite exposure, the cause of the plaques remains unclear. Moreover, our findings indicate that, under the exposure conditions of the Finnish mine and mill in our study, wollastonite fibers are poorly retained in human 
lungs. This finding may also explain the absence of fibrosis in our material.

\section{Acknowledgments}

We wish to thank the workers who participated in this study, and the Partek Company for its financial support. We also thank Terttu Kaustia, MA, who revised the language of this communication.

\section{References}

1. Huuskonen MS, Tossavainen A, Koskinen H, Zitting A, Korhonen $\mathrm{O}$, Nickels $\mathbf{J}$ et al. Wollastonite exposure and lung fibrosis. Environ Res 1983;30:291-304.

2. Hanke W, Sepulveda M-J, Watson A, Jankovic. Respiratory morbidity in wollastonite workers. Br J Ind Med 1984;4:47479.

3. Pyy L, Hartikainen T, Junttila S, Korhonen K, Tossavainen A, Suominen V, et al. Kuitumineraalien esiintyminen Suomen kalkkikaivoksissa ja kalliomurskelaitoksissa [The occurrence of fibrous minerals in Finnish calcite mines and quarries]. Helsinki: Finnish Institute of Occupational Health, 1993. Final report of the Finnish Work Environment Fund project No. 92019.

4. Huuskonen MS, Järvisalo J, Koskinen H, Nickels J, Räsänen $\mathrm{J}$, Asp S. Preliminary results from a cohort of workers exposed to wollastonite in a Finnish limestone quarry. Scand J Work Environ Health 1983;9:169 - 75.

5. International Labour Office (ILO). ILO international classification of radiographs of pneumoconioses, 1980. Geneva: ILO, 1980. Occupational safety and health series, no 22 revised.

6. Medical Research Council. Definition and classification of chronic bronchitis for clinical and epidemiological purposes. Lancet 1965;1:775-9.

7. Lynch DA, Gamsu G, Aberle DR. Conventional and high resolution computed tomography in the diagnosis of asbestosrelated disease. Radiographics 1989;9:523 - 51 .

8. Viljanen A, editor. Reference values for spirometric, pulmonary diffusion capacity and body plethysmographic studies. Scand J Clin Lab Invest 1982;42 suppl 159:1 - 50.

9. Klech H, Pohl W, editors. Technical recommendations and guidelines for bronchoalveolar lavage (BAL): report of the European Society of Pneumology Task Group on BAL. Eur Respir J 1989;2:561—85.

10. Tuomi T, Oksa P, Anttila S, Taikina-aho O, Taskinen E, Karjalainen A, et al. Fibres and asbestos bodies in bronchoalveolar lavage fluids of asbestos sprayers. Br J Ind Med 1992; 49:480-85.

11. Chatfield EJ. Short mineral fibres in airborne dust. In: Chatfield EJ, Elmes PC, Muhle H, Pott F, Pooley FD, editors. Short and thin mineral fibres: identification, exposure and health effects. Solna (Sweden): National Board of Occupational Safety and Health Research Department, 1983:10 -93.

12. Karjalainen A, Anttila S, Mäntylä T, Kyyrönen P, Tukiainen P. Asbestos bodies in bronchoalveolar lavage fluid in relation to occupational history. Am J Ind Med 1994;26:645-54.

13. Taikina-aho O, Anttila S, Pääkkö P, Sivonen SJ, Kalliomäki PL. Environmnetal pulmonary mineral particle burden correlated with smoking, pulmonary emphysema and lung cancer. In: National Institute for Occupational Safety and Health (NIOSH). Proceedings of the VII International Pneumoconioses Conference, Pittsburgh PA, August 23-26, 1988. Cincinnati (OH): NIOSH 1990:1077-82. DHHS publication, no 90108, pt II.

14. Aberle DR, Balmes JR. Computed tomography of asbestosrelated pulmonary parenchymal and pleural diseases. Clin Chest Med 1991;1:115-31.

15. Larsen G. Experimental data on in vitro fibre solubility. In: Bignon J, Peto J, Saracci R, editors. Non-occupational exposure to mineral fibres. Lyon: International Agency for Research on Cancer, 1989:134-9. Scientific publications, no 90.

16. Warheit DB, Hartsky MA, McHugh TA, Kellar KA. Biopersistence of inhaled organic and inorganic fibers in the lungs of rats. Environ Health Perspect 1994;102 suppl 5:151—7.

Received for publication 22 April 1996 